\title{
Anaerobic taurine oxidation: a novel reaction by a nitrate-reducing Alcaligenes sp.
}

\author{
Karin Denger, Heike Laue and Alasdair M. Cook \\ Author for correspondence: Alasdair M. Cook. Tel: +49753188 4247. Fax: +497531 882966. \\ e-mail: Alasdair.Cook (a) uni-konstanz.de
}

Faculty for Biology, The University, D-78434 Konstanz Germany

\begin{abstract}
Enrichment cultures were prepared under strictly anoxic conditions in medium representing fresh water and containing an organosulfonate as electron donor and carbon source, and nitrate as electron acceptor. The inoculum was from the anaerobic digestor of two communal sewage works. The natural organosulfonates 2-aminoethanesulfonate (taurine), DL-2-amino-3sulfopropionate (cysteate) and 2-hydroxyethanesulfonate (isethionate) all gave positive enrichments, whereas unsubstituted alkanesulfonates, such as methanesulfonate and arenesulfonates, gave no enrichment. Two representative enrichments were used to obtain pure cultures, and strains NKNTAU (utilizing taurine) and NKNIS (utilizing isethionate) were isolated. Strain NKNTAU was examined in detail. Out of 18 tested organosulfonates, it utilized only one, taurine, and was identified as a novel Alcaligenes sp., a facultatively anaerobic bacterium. Carbon from taurine was converted to cell material and carbon dioxide. The amino group was released as ammonium ion and the sulfonate moiety was recovered as sulfate. Nitrate was reduced to nitrogen gas.
\end{abstract}

Keywords: desulfonation, taurine, nitrate-reducing bacteria, anaerobic degradation, anaerobic desulfonation

\section{INTRODUCTION}

Taurine (2-aminoethanesulfonate) was discovered in 1836 and is found in high concentrations in algae, insects and other arthropods, and in mammals (e.g. $1 \mathrm{~g} \mathrm{~kg}^{-1}$ in man, where it is the most abundant solute) (Huxtable, 1992). Many physiological functions of taurine in mammals are known or suspected, and a major role under anoxic conditions is as bile acids in the gut (Huxtable, 1992). Mammals are unable to oxidize taurine or to attack the carbon-sulfur bond, so microorganisms are essential to degrade this organosulfonate compound.

Taurine has been recognized as a nutrient for aerobic bacteria since 1926, when its utilization as a sole nitrogen source was observed (den Dooren de Jong, 1926), and utilization as a sole source of carbon (e.g. Ikeda et al., 1963) or of sulfur (Roberts et al., 1955) were subsequently noted. Variants of the degradative pathway for taurine as a carbon source for bacteria were established by two groups (e.g. Kondo \& Ishimoto, 1975, 1987; Shimamoto \& Berk, 1980), and it is becoming apparent

The NCBI GenBank accession number for the nucleotide sequence determined in this work is U82826. that different enzymology and regulation are involved when taurine is utilized as a source of sulfur (Kertesz et al., 1994; van der Ploeg et al., 1996).

Review articles discounted the reports of anaerobic desulfonation made before 1994 (Fuchs et al., 1994; Painter \& Mosey, 1992), but shortly thereafter, the assimilation of taurine sulfur during growth of facultatively anaerobic and of strictly anaerobic bacteria was reported (Chien et al., 1995; Denger \& Cook, 1997; Denger et al., 1996). Indeed, the first reports of dissimilatory metabolism of organosulfonates by strictly anaerobic bacteria have been made (Lie et al., 1996; Laue et al., 1997); they involve principally isethionate or taurine, which are reduced in anaerobic respiration. We now report on another novel aspect of the dissimilatory metabolism of taurine under anoxic conditions. We have isolated what appears to be a new species of Alcaligenes, strain NKNTAU, that can utilize taurine as a source of electrons and carbon under anoxic, nitraterespiring conditions.

\section{METHODS}

Materials. The sulfonates used were of high purity (about $99 \%$ ) from TCI, Sigma-Aldrich, Fluka or Merck and were used as supplied by the manufacturer. Gases $\left(\mathrm{N}_{2}, \mathrm{CO}_{2}\right.$ and $\left.\mathrm{H}_{2}\right)$ 
were obtained from Messer Griesheim. The inocula were anaerobic sludges from the anaerobic stages of the communal wastewater treatment plants in Konstanz $(\mathrm{KN})$ and Radolfzell (RZ), Germany.

Growth media and the generation of pure cultures. Enrichment cultures were done in a basal salts medium representing fresh water, prepared anoxically as described by Widdel \& Pfenning (1981). The basal salts were buffered with $50 \mathrm{mM} \mathrm{NaHCO}_{3}$, and supplemented with trace-element solution SL 10 (Widdel et al., 1983), selenite/tungstate solution (Tschech \& Pfennig, 1984), seven-vitamin solution (Pfennig, 1978), $2 \mu \mathrm{M}$ resazurin and, as a reductant, titanium(III) nitrilotriacetate (to about $0.5 \mathrm{mM}$ ) (cf. Denger et al., 1996). The medium contained $200 \mu \mathrm{M}$ sodium sulfide as a source of sulfur. The $\mathrm{pH}$ of the medium was adjusted to $\mathrm{pH} 7 \cdot 0-7 \cdot 1$ and $25 \mathrm{ml}$ portions were transferred to $50 \mathrm{ml}$ infusion bottles sealed with butyl rubber septa. An organosulfonate was added to $20 \mathrm{mM}$ sulfonate anion, and the inoculum $(5 \%, \mathrm{v} / \mathrm{v})$ was untreated anaerobic sludge. Cultures were incubated at $30^{\circ} \mathrm{C}$ under an atmosphere of $\mathrm{N}_{2}$ plus $\mathrm{CO}_{2}(80: 20, \mathrm{v} / \mathrm{v})$. Pure cultures were obtained by the repeated application of the agar shake method (Pfennig, 1978). Culture purity was checked microscopically and by growth tests on complex media (AC-medium and plate-count-agar, Difco).

Growth experiments with the pure culture(s) were done with $1 \mathrm{mM}$ titanium(III) nitrilotriacetate in the absence of redox indicator; the redox indicator was eliminated to avoid analytical problems so the concentration of reductant was increased as a precaution. When ammonium ion was to be quantified, the basal medium was altered to contain $0.5 \mathrm{mM}$ anmonium ion instead of $4.7 \mathrm{mM}$. Detailed growth experiments (e.g. Fig. 2) were set up with $50 \mathrm{ml}$ medium in $100 \mathrm{ml}$ infusion bottles. Experiments solely to measure end-points were done with $10 \mathrm{ml}$ cultures in $20 \mathrm{ml}$ tubes.

Growth and the preparation of cell-free extracts. Growth was followed routinely by measuring the optical density at $580 \mathrm{~nm}$ and quantified by determination of protein by a Lowry-type method (Cook \& Hütter, 1981). Samples were taken at intervals through the septum by a syringe. Cells for the preparation of cell-free extract were harvested anoxically at the end of the exponential growth phase $(2000 \mathrm{~g}, 20 \mathrm{~min}$, $4{ }^{\circ} \mathrm{C}$ ) and disrupted by three passages through a chilled French pressure cell (140 MPa). Cell debris was removed by centrifugation $\left(3000 \mathrm{~g}, 20 \mathrm{~min}, 4^{\circ} \mathrm{C}\right)$. Cytochromes were assayed in cell-free extracts as well as in soluble protein fractions and membrane preparations obtained by ultracentrifugation $(150000 \mathrm{~g}, 2 \mathrm{~h}$ ).

Analytical methods. The HPLC system used was equipped with a diode array detector. Reverse-phase chromatography was done as described elsewhere (Laue et al., 1996). Ion chromatography with suppression and conductivity detection was done with Sykam apparatus (Laue et al., 1996).

Taurine was routinely quantified by HPLC after derivatization with 2,4-dinitrofluorobenzene (DNFB) (Sanger, 1945). Sample $(0.02 \mathrm{ml}, 0-20 \mathrm{nmol}$ taurine) was added to $1.0 \mathrm{ml} 0.1 \mathrm{M}$ $\mathrm{NaHCO}_{3}$ and $0.2 \mathrm{ml} 5 \%(\mathrm{v} / \mathrm{v})$ DNFB in ethanol. The reaction mixture was shaken for $2 \mathrm{~h}$ at room temperature and the reaction was stopped by acidification with two drops of concentrated $\mathrm{HCl}$. The derivatization product was stable for at least $20 \mathrm{~h}$. It was quantified by HPLC with a methanol gradient $(0-60 \%)$ in $10 \mathrm{mM}$ potassium phosphate mobile phase at $\mathrm{pH} \mathrm{2} 2$, and with the detector set at $360 \mathrm{~nm}$. We occasionally confirmed these data by derivatizing with $o$ phthaldialdehyde (Stipanuk et al., 1987). Nitrate and nitrite were quantified routinely by ion chromatography as described elsewhere (Laue et al., 1996). We occasionally confirmed nitrate and nitrite determinations colorimetrically with the chromotropic acid method (Lange \& Vejdelek, 1980) and sulfanilic acid/ $\alpha$-naphthylamine [Gesellschaft Deutscher Chemiker (GDCh), 1996], respectively, and with analytical test strips (Merckoquant; Merck). Ammonium ion was routinely assayed photometrically by the Berthelot reaction (GDCh, 1996). Some of these data were confirmed enzymically with glutamate dehydrogenase (Bergmeyer, 1983) and by flow injection analysis (Hall \& Aller, 1992). Sulfate ion was assayed as the optical density of a suspension of insoluble $\mathrm{BaSO}_{4}$ (Schauder et al., 1986). Some of these data were confirmed by ion chromatography, which was also used to measure sulfite ion (Laue et al., 1996). rDNA was sequenced by the German Culture Collection (DSMZ, Braunschweig, Germany), Genomic DNA extraction, PCR-mediated amplification of about $95 \%$ of the $16 \mathrm{~S}$ rDNA and purification of the PCR products were done as described elsewhere (Rainey et al., 1996). Purified PCR products were sequenced with the $513 \mathrm{r}$ primer using the ABI PRISM dye terminator cycle sequencing ready reaction kit (Applied Biosystems) as in the manufacturer's protocol. Sequence reactions were electrophoresed using the Applied Biosystems 373A DNA sequencer. DSMZ analysed the data in alignment editor ae2 (Maidak et al., 1996), aligning manually, and compared them with the currently available $16 \mathrm{~S}$ rRNA gene sequences of representative micro-organisms belonging to the beta-subdivision of the Proteobacteria. Total organic carbon was determined in a total organic carbon analyser (GDCh, 1996). Oxidase and catalase tests were carried out following standard methods (Gerhardt et al., 1994).

\section{RESULTS}

\section{Enrichment and isolation of bacteria utilizing organosulfonates as sources of electrons}

Anoxic enrichment cultures (11 pairs with different inocula) were set up with $10 \mathrm{mM}$ nitrate as electron acceptor and single alkanesulfonates [methane-, ethane-, 1-heptane- and aminomethanesulfonates, 2-aminoethanesulfonate (taurine), 2-hydroxyethanesulfonate (isethionate) and 2-amino-3-sulfopropionate (cysteate)] or arenesulfonates (benzene- and toluenesulfonates, 4sulfobenzoate and 2,6-naphthalenedisulfonate) as sole sources of electrons and carbon. Turbidity developed within 3-4 days in positive cultures, where growth was also indicated by gas bubbles (probably $\mathrm{N}_{2}$ ) rising from the sediment and by increased pressure in the culture vessels. The resazurin indicator was always colourless, indicating that anoxic conditions were maintained throughout growth. After several transfers, the cell population stabilized (consisting of mostly small rods of about $1 \times 0.3 \mu \mathrm{m}$ ). Two controls each were then done with the nine putatively positive enrichment cultures (six from the Konstanz inoculum), to check whether growth was possible in the absence of nitrate or in the absence of the sulfonate electron donor. The enrichments with methanesulfonate, ethanesulfonate or naphthalenedisulfonate as the putative electron source grew in the absence of the sulfonate and the culture medium contained white precipitate after growth. There was no growth of these cultures in the absence of nitrate, so we attributed growth to utilization of the nitrilo- 


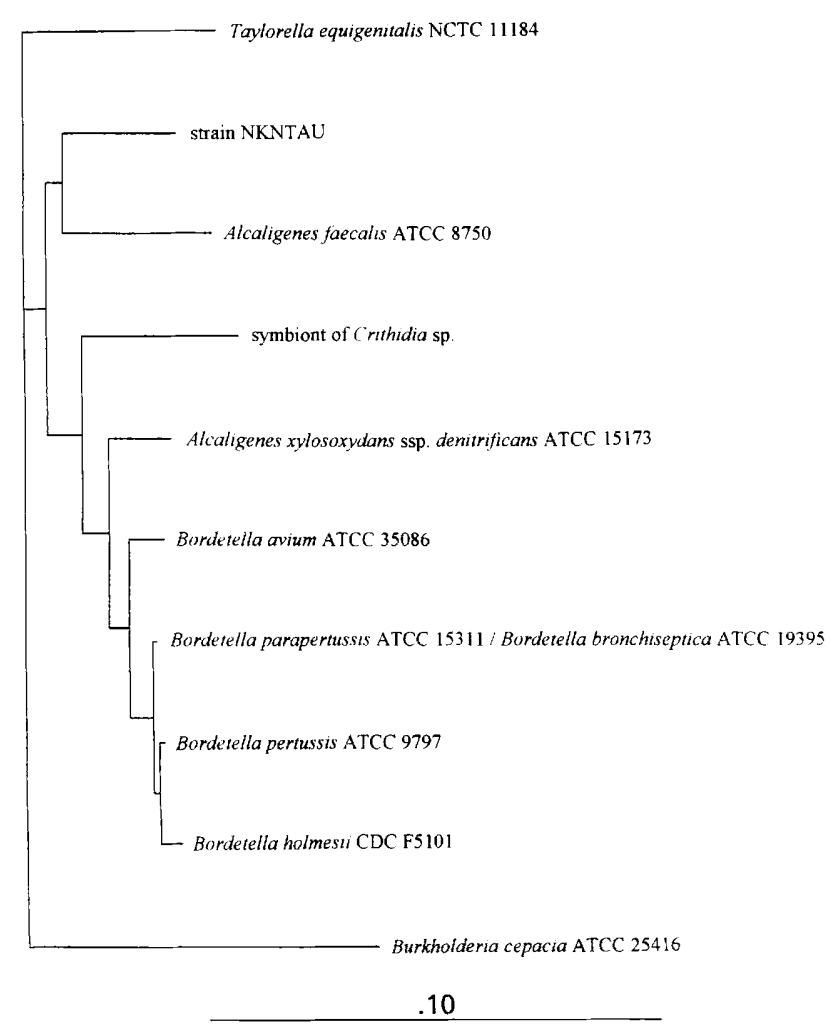

Fig. 1. Dendrogram of evolutionary distances based on $16 \mathrm{~S}$ rRNA sequences from strain NKNTAU and nine reference organisms of the Bordetella group in the $\beta$-subdivision of the Proteobacteria. The dendrogram was constructed using the phylogeny inference package (Felsenstein, 1993), incorporating phylogenetic distances (Jukes \& Cantor, 1969) and the neighbour-joining method (Saitou \& Nei, 1987). The scaling indicates 10 nucleotide substitutions per 100 nucleotides.

triacetate chelator in the medium. Degradation of the chelator presumably caused titanium(III) to precipitate, and these cultures were abandoned. We therefore had six authentic enrichment cultures (three from each inoculum), two each with the natural products taurine, isethionate and cysteate. Growth was observed only in the presence of both the sulfonate and nitrate. The pairs were microscopically indistinguishable. The two fastestgrowing enrichments, one each with taurine and isethionate, were chosen and two pure cultures (strains NKNTAU and NKNIS) were isolated from selective medium using the agar shake method. The isolates were morphologically similar, and we chose to work largely with the taurine utilizer, strain NKNTAU, because our derivatization of substrate was optimized for taurine.

\section{Identification of strain NKNTAU}

Cells of strain NKNTAU were small, slightly curved rods $(1 \times 0.2-0.3 \mu \mathrm{m})$ which were motile in fresh cultures. The bacterium was oxidase-positive and catalase-positive. It could utilize molecular oxygen as terminal electron acceptor on, for example, plate-countagar and was therefore facultatively anaerobic. Strain NKNTAU oxidized taurine with oxygen, nitrate, nitrite or nitrous oxide as electron acceptor. Taurine was not oxidized in the presence of dimethylsulfoxide, fumarate, sulfate, sulfite or thiosulfate. We found that Bilophila wadsworthia RZATAU grew with taurine as electron acceptor and formate as electron donor (Laue et al., 1997); strain NKNTAU did not grow under such conditions. Chemolithoautotrophic growth with $\mathrm{CO}_{2}$ as sole carbon source and $\mathrm{H}_{2}$ or formate as electron donors was not observed. No fermentative growth was detected with taurine, or with glucose, fructose or lactate as substrates. Metabolism was thus strictly oxidative.

Cytochromes were detected in both the soluble and the particulate fractions of crude extracts of strain NKNTAU. The absorption bands at $417 \mathrm{~nm}, 521 \mathrm{~nm}$ and $552 \mathrm{~nm}$ in redox difference spectra of the soluble protein fraction indicated a $c$-type cytochrome, whereas bands at $426 \mathrm{~nm}$ and $557 \mathrm{~nm}$ in the membrane fraction indicated a $b$-type cytochrome (Voet \& Voet, 1992). Assuming an $M_{\mathrm{r}}$ of 12000 and an absorption coefficient for the $\alpha$-peak of $19.0 \mathrm{mM}^{-1} \mathrm{~cm}^{-1}$ (Chance $\&$ Williams, 1955), the cytochrome $c$ content of the soluble fraction and the cytochrome $b$ content in the membrane fraction were both about $1-2 \mathrm{mg}$ (g protein) ${ }^{-1}$.

The bacterium was deposited as DSM 11046 with the German Culture Collection (DSMZ). 16S rDNA from the organism was sequenced and the data analysed as described in Methods. Strain NKNTAU was attributed to the Bordetella group, where it probably represents a new species of Alcaligenes, because its closest neighbour, Alcaligenes faecalis, has only $95 \%$ identity (Fig. 1).

\section{Growth physiology of Alcaligenes sp. strain NKNTAU}

A broad variety of alkane- and arenesulfonates and related substrates were tested as electron and carbon sources under nitrate-reducing conditions. Of the 18 compounds tested, only taurine was utilized. Methanesulfonate, ethanesulfonate, 1-heptanesulfonate, aminomethanesulfonate, isethionate, cysteamine, 2bromoethanesulfonate, coenzyme $M$, cysteate, benzenesulfonate, 4-toluenesulfonate, 4-sulfobenzoate, 2,6naphthalenedisulfonate, 2-aminobenzenesulfonate, $\mathrm{N}$ cyclohexanesulfaminate, 3-cyclohexylaminopropanesulfonate and N-2-hydroxyethylpiperazine- $N^{\prime}-2$ ethanesulfonate were not. Strain NKNTAU is apparently a specialist, so far as sulfonates are concerned.

Acetate and ethanol, and propionate and propanol, but not formate or methanol, were oxidized at the expense of nitrate.

Strain NKNTAU grew exponentially (reproducibly, $\mu=0.07 \mathrm{~h}^{-1}$ ) with taurine as sole source of electrons and carbon, and with nitrate as the electron acceptor (Fig. 2). Growth (protein formation) was concomitant with the utilization of taurine (Fig. 2, inset) and with the utilization of nitrate (not shown); no nitrite was detected under these conditions and the reaction was presumed to proceed to $\mathrm{N}_{2}$. Two products, namely ammonium and sulfate ions, were observed to be formed concomitantly with growth. Ammonium ion was tentatively 


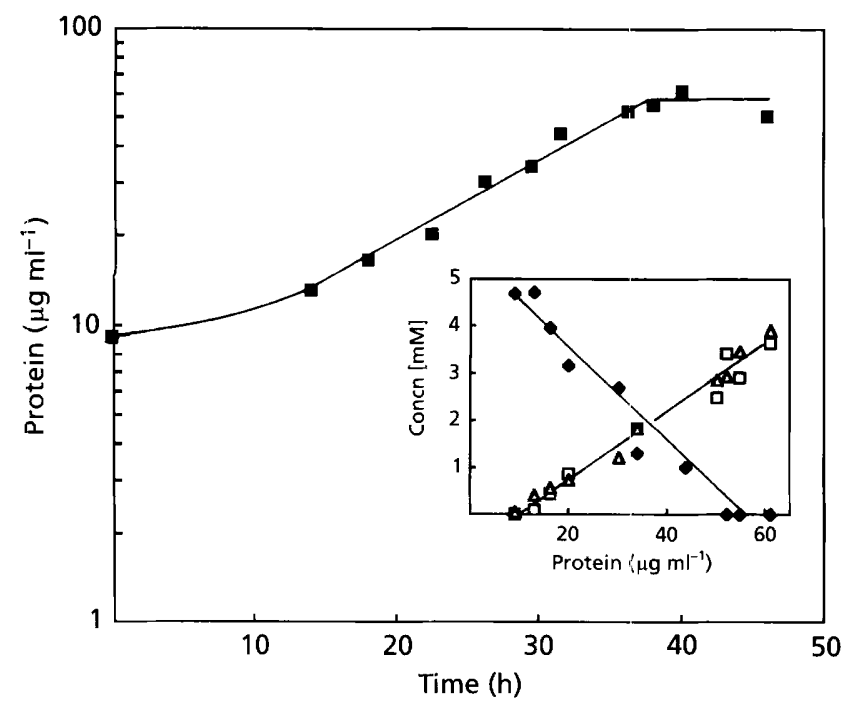

Fig. 2. Growth of Alcaligenes sp. strain NKNTAU in anoxic taurine/nitrate salts medium. The inset shows taurine degradation $(\diamond)$ and formation of ammonium ion $(\Delta)$ and sulfate ion ( $\square$ ) as a function of protein formation.

identified and routinely determined colorimetrically and its identity was confirmed in the specific reaction with glutamate dehydrogenase. Sulfate was tentatively identified and routinely assayed as a precipitate of barium sulfate, and the identification of this sulfate was confirmed by co-chromatography with authentic material during ion chromatography. Dissolved organic carbon was measured in medium after growth with complete substrate utilization in taurine/salts and in acetate/salts medium. The values were identical, representing some cell lysis, so we presume that no significant unknown product was formed from taurine. No ammonium ion was formed during growth in acetate/salts medium. If cells were grown with excess nitrate, all nitrate was reduced but nitrite was recovered in the medium.

The stoichiometry of growth (Table 1 ) was considered to comprise two formal components, dissimilation and assimilation. The observed data for dissimilation indicated that $2.3 \mathrm{~mol}$ nitrate ( $\mathrm{mol}$ taurine) ${ }^{-1}$ was required (Table 1). We interpret this to represent a ratio of $2 \cdot 4$, as in equation (1), because the latter value gives a balanced equation:

$$
\begin{array}{r}
1 \mathrm{C}_{2} \mathrm{H}_{7} \mathrm{NSO}_{3}+2 \cdot 4 \mathrm{NO}_{3}^{-}+1 \cdot 4 \mathrm{H}^{+} \rightarrow 2 \mathrm{CO}_{2}+1 \cdot 2 \mathrm{~N}_{2} \\
+1 \mathrm{NH}_{4}^{+}+1 \mathrm{SO}_{4}^{2-}+2 \cdot 2 \mathrm{H}_{2} \mathrm{O}
\end{array}
$$

The assimilation of carbon also required nitrate as an electron acceptor. Cell material was considered to be equivalent to the composition of glucose, which would arise from the following equation (2):

$$
\begin{aligned}
15 \mathrm{C}_{2} \mathrm{H}_{7} \mathrm{NSO}_{3}+12 \mathrm{NO}_{3}^{-}+3 \mathrm{OH}^{-}+6 \mathrm{H}_{2} \mathrm{O} \rightarrow \\
5 \mathrm{C}_{6} \mathrm{H}_{12} \mathrm{O}_{6}+15 \mathrm{SO}_{4}^{2-}+15 \mathrm{NH}_{4}^{+}+6 \mathrm{~N}_{2}
\end{aligned}
$$

Whereas strain NKNTAU has been studied in some detail, we have only preliminary data with strain

Table 1. Stoichiometry of anoxic growth of Alcaligenes sp. strain NKNTAU in taurine/salts medium

The data are the mean values of four replicate experiments.

Protein formed*
Taurine consumed
Taurine assimilated $\dagger$
Taurine dissimilated $\ddagger$
Nitrate consumed*
Nitrate reduced during assimilation
of taurine $\dagger$
Nitrate dissimilated $\ddagger$
Nitrate dissimilated/taurine
dissimilated
Electron balance
Ammonia released*
Ammonia assimilated $\dagger$
Taurine nitrogen recovered
Sulfate formed*
Sulfur recovery $\dagger$
Molar growth yield
$0.6 \mathrm{mg}$
$43 \cdot 0 \mu \mathrm{mol}$
$19 \cdot 2 \mu \mathrm{mol}$
$23 \cdot 8 \mu \mathrm{mol}$
$70 \cdot 0 \mu \mathrm{mol}$
$15 \cdot 6 \mu \mathrm{mol}$
$54 \cdot 4 \mu \mathrm{mol}$
$2 \cdot 3$
$105 \%$
$37 \cdot 0 \mu \mathrm{mol}$
$12 \cdot 0 \mu \mathrm{mol}$
$114 \%$
$42 \cdot 0 \mu \mathrm{mol}$
$98 \%$
$7 \mathrm{~g}$ protein $(\mathrm{mol} \mathrm{C})^{-1}$

* Direct determination.

tCalculated on the basis that cell material consists of $50 \%$ protein, $50 \%$ carbon, $14 \%$ nitrogen (Luria, 1960) and negligible sulfur, and from equation (2), therefore for synthesis of $1 \mathrm{mg}$ of protein, $32 \mu \mathrm{mol}$ taurine and $26 \mu \mathrm{mol}$ nitrate were consumed.

‡Calculated as the difference between total consumption and assimilation.

NKNIS, which showed nitrate-dependent growth with isethionate and taurine but not with cysteate. After growth of strain NKNIS (and only this strain) in isethionate-salts medium, we could detect sulfite in millimolar concentrations. This organism differed morphologically from strain NKNTAU in being more coccoid $(0 \cdot 8 \times 0.4 \mu \mathrm{m})$. The mixed culture NKNCYSA utilized only cysteate, and the major organism in the culture was a motile rod $(2-3 \times 0.5 \mu \mathrm{m})$. Sulfate was detected as a reaction product in each case. No sulfide was detected in this work.

\section{DISCUSSION}

We have isolated the first bacteria able to dissimilate sulfonates under anoxic nitrate-reducing conditions. The data are thorough, at least for Alcaligenes sp. strain NKNTAU. There is no evidence for missing products, so the formal oxidations represented in equations (1) and (2) show that carbon from taurine is converted to $\mathrm{CO}_{2}$ and cell material. The nitrogen from taurine is converted to ammonium ion, which was thoroughly identified, and part of which is assimilated into cell material. No ammonium ion is formed when the cells utilize acetate under these conditions, so no ammonium is derived from nitrate. The sulfonate moiety from taurine was recovered quantitatively as sulfate, which 
was also thoroughly identified, so the sulfonate moiety was oxidized in the course of metabolism. This oxidation, together with the oxidation of the carbon moiety in the formal representation of assimilatory metabolism [equation (2)], explains the requirement for nitrate in the assimilatory reaction.

We have detailed information on only one bacterium, which has a narrow substrate range for sulfonates. Our second isolate, strain NKNIS, and the mixed culture NKNCYSA, also had limited substrate ranges and share with Alcaligenes sp. strain NKNTAU the formation of sulfate from the sulfonate. Release of sulfite ion from the sulfonate moiety by strain NKNIS was observed, so sulfite could be the first product released upon cleavage of the $\mathrm{C}-\mathrm{SO}_{3}^{-}$bond. All six enrichment cultures with the naturally occurring, substituted alkanesulfonates were positive, so we suspect that we have observed a widespread phenomenon. We support this argument with the widespread distribution of these three natural organosulfonates, especially taurine (see Introduction).

Our enrichment medium turned out to have insufficient nitrate. This was, however, preferable to having an excess, which accumulated as the potentially toxic nitrite. We optimized our growth conditions to utilize both electron donor and electron sink with negligible excess of either at the end of growth. Our work with sulfonates, with the requirement to determine and identify sulfur-containing species, eliminates the use of sulfur-containing reducing agents, or those which could precipitate sulfur species from the medium. We therefore used titanium(III) as reductant (Zehnder \& Wuhrmann, 1976), and we used a modification of the original procedure, with citrate as the anion, involving the less widely utilized nitrilotriacetate (NTA). We have unintentionally confirmed the ease with which anoxic degraders of NTA can be isolated (Wanner et al., 1990), and we foresee a further alteration of the medium to using EDTA, in place of NTA, to try to obtain isolates that are able to utilize the naturally occurring methanesulfonate (Baker et al., 1991), whose degradation in the anaerobic digestor is obviously less common than that of taurine, if it occurs at all.

Alcaligenes sp. strain NKNTAU is a facultatively anaerobic bacterium with a strictly oxidative metabolism. We therefore presume that the cytochromes $c$ and $b$ and the cytochrome $c$ oxidase that we detect are involved in electron transport processes, presumably, in part, in the nitrate respiration. The molar growth yield of strain NKNTAU, at $7 \mathrm{~g}$ protein $(\mathrm{mol} \mathrm{C})^{-1}$ (Table 1), is typical of that for an aerobic organism (Cook, 1987). A truly anaerobic degradative scheme would surely involve a more efficient utilization of the free energy change of the reaction $\left[\Delta G_{0}{ }^{\prime}=-1223.4 \mathrm{~kJ}\right.$ (mol taurine $)^{-1}$, calculated after Thauer et al. (1977)]. The fact that taurine is utilized under aerobic and anoxic conditions opens the question as to whether the same metabolic enzymes are involved in these phenomena, or whether different pathways or isoenzymes for taurine degradation are present. Indeed, we wonder whether the same basic pathway for taurine degradation already found in aerobes (Kondo \& Ishimoto, 1975, 1987; Shimamoto \& Berk, 1980) is also central to the reduction of taurine in an anaerobic respiration, which we recently discovered (Laue et al., 1997). If that idea is correct, then nature has used one pathway as a module in many different metabolic settings.

\section{ACKNOWLEDGEMENTS}

K.D. was supported by a grant from the Deutsche Forschungsgemeinschaft. We thank Dr H. H. Stabel, Bodenseewasserversorgung, Sipplingen, Germany, for the determinations of total organic carbon and C. Bareiß for experiments done during a practical course.

\section{REFERENCES}

Baker, S. C., Kelly, D. P. \& Murrell, J. C. (1991). Microbial degradation of methanesulphonic acid: a missing link in the biogeochemical sulphur cycle. Nature 350, 627-628.

Bergmeyer, H. U. (1983). Methods of Enzymatic Analysis. 3rd edn. Weinheim: Verlag Chemie.

Chance, B. \& Williams, G. R. (1955). Respiratory enzymes in oxidative phosphorylation. II. Difference spectra. J Biol Chem 217, 395-407.

Chien, C.-C., Leadbetter, E. R. \& Godchaux, W., III (1995). Sulfonate-sulfur can be assimilated for fermentative growth. FEMS Microbiol Lett 129, 189-194.

Cook, A. M. (1987). Biodegradation of $s$-triazine xenobiotics. FEMS Microbiol Rev 46, 93-116.

Cook, A. M. \& Hütter, R. (1981). s-Triazines as nitrogen sources for bacteria. J Agric Food Chem 29, 1135-1143.

Denger, K. \& Cook, A. M. (1997). Assimilation of sulfur from alkyl- and arylsulfonates by Clostridium spp. Arch Microbiol 167, 177-181.

Denger, K., Kertesz, M. A., Vock, E., Schön, R., Mägli, A. \& Cook, A. M. (1996). Anaerobic desulfonation of 4-tolylsulfonate and 2(4-sulfophenyl)butyrate by Clostridium sp. Appl Environ Microbiol 62, 1526-1530.

den Dooren de Jong, L. E. (1926). Bijdrage tot de Kennis van het Mineralisatieproces. Rotterdam: Nijgh \& van Ditmar.

Felsenstein, J. (1993). PHYLIP - phylogeny inference package. Seattle: Department of Genetics, University of Washington, USA.

Fuchs, G., Mohamed, M. E. S., Altenschmidt, U., Koch, J., Lack, A., Brackmann, R., Lochmeyer, C. \& Oswald, B. (1994). Biochemistry of anaerobic biodegradation of aromatic compounds. In Biochemistry of Microbial Degradation, pp. 513-553. Edited by C. Ratledge. Dordrecht: Kluwer.

Gesellschaft Deutscher Chemiker (1996). German Standard Methods for the Laboratory Examination of Water, Waste Water and Sludge. Weinheim: VCH.

Gerhardt, P., Murray, R. G. E., Wood, W. A. \& Krieg, N. R. (1994). Methods for General and Molecular Bacteriology. Washington, DC: American Society for Microbiology.

Hall, O. J. \& Aller, R. C. (1992). A rapid, small-volume, flow injection analysis for $\mathrm{CO}_{2}$ and $\mathrm{NH}_{4}^{+}$in marine and freshwaters. Limnol Oceanogr 37, 1113-1119.

Huxtable, R. J. (1992). Physiological actions of taurine. Physiol Rev 72, 101-163. 
Ikeda, K., Yamada, H. \& Tanaka, S. (1963). Bacterial degradation of taurine. J Biochem 54, 312-316.

Jukes, T. H. \& Cantor, C. R. (1969). Evolution of protein molecules. In Mammalian Protein Metabolism, pp. 21-132. Edited by H. N Munro. New York: Academic Press.

Kertesz, M. A., Cook, A. M. \& Leisinger, T. (1994). Microbial metabolism of sulfur- and phosphorus-containing xenobiotics FEMS Microbiol Rev 15, 195-215.

Kondo, H. \& Ishimoto, M. (1975). Purification and properties of sulfoacetaldehyde sulfo-lyase, a thiamine pyrophosphate-dependent enzyme forming sulfite and acetate. J Biochem 78, 317-325.

Kondo, H. \& Ishimoto, M. (1987). Taurine dehydrogenase. Methods Enzymol 143, 496-499.

Lange, B. \& Vejdelek, Z. J. (1980). Photometrische Analyse. Weinheim: Verlag Chemie.

Laue, H., Field, J. A. \& Cook, A. M. (1996). Bacterial desulfonation of the ethanesulfonate metabolite of the chloroacetanilide herbicide metazachlor. Environ Sci Technol 30, 1129-1132.

Laue, H., Denger, K. \& Cook, A. M. (1997). Taurine reduction in anaerobic respiration of Bilophila wadsworthia RZATAU. Appl Environ Microbiol 63, (in press)

Lie, T. J., Pitta, T., Leadbetter, E. R., Godchaux, W., III \& Leadbetter, J. R. (1996). Sulfonates: novel participants in anaerobic respiration. Arch Microbiol 166, 204-210.

Luria, S. E. (1960). The bacterial protoplasm: composition and organization. In The Bacteria, vol. 1, pp. 1-34. Edited by I. C. Gunsalus \& R. Y. Stanier. New York: Academic Press.

Maidak, B. L., Olsen, G. L., Larsen, N., McCaughey, M. J. \& Woese, C. R. (1996). The ribosomal database project (RDP). Nucleic Acids Res 24, 82-85.

Painter, H. A. \& Mosey, F. E. (1992). The anaerobic biodegradability of linear alkyl benzene sulfonate (LAS). In Proceedings of the 3rd CESIO International Surfactant Congress, London, UK, 1-5 June, 1992, pp. 34-43.

Pfennig, N. (1978). Rhodocyclus purpureus gen. nov. sp. nov., a ring-shaped, vitamin $\mathrm{B}_{12}$-requiring member of the family $R$ hodospirillaceae. Int J Syst Bacteriol 28, 283-288.

van der Ploeg, Weiss, M., Saller, E., Nashimoto, H., Saito, N., Kertesz, M. A. \& Leisinger, T. (1996). Identification of sulfate starvation-regulated genes in Escherichia coli: a gene cluster involved in the utilization of taurine as a sulfur source. J Bacteriol $178,5438-5446$.

Rainey, F. A., Ward-Rainey, N., Kroppenstedt, R. M. \& Stackebrandt, E. (1996). The genus Nocardiopsis represents a phylogenetically coherent taxon and a distinct actinomycete lineage: proposal of Nocardiopsaceae fam. nov. Int J Syst Bacteriol 46, 1088-1092.

Roberts, R. B., Cowie, D. B., Abelson, P. H., Bolton, E. T. \& Britten, R. J. (1955). Sulfur metabolism. In Studies of Biosynthesis in
Escherichia coli, pp. 318-405. Edited by R. B. Roberts, D. B. Cowie, P. H. Abelson, E. T. Bolton \& R. J. Britten. Washington, DC: Carnegie Institution of Washington.

Saitou, N. \& Nei, M. (1987). The neighbor-joining method: a new method for reconstructing phylogenetic trees. Mol Biol Evol 4, 406-425.

Sanger, F. (1945). The free amino groups of insulin. Biochem J 39, 507-515.

Schauder, R., Eikmanns, B., Thauer, R. K., Widdel, F. \& Fuchs, G. (1986). Acetate oxidation to $\mathrm{CO}_{2}$ in anaerobic bacteria via a novel pathway not involving reactions of the citric acid cycle. Arch Microbiol 145, 162-172.

Shimamoto, G. \& Berk, R. S. (1980). Taurine catabolism. II. Biochemical and genetic evidence for sulfoacetaldehyde sulfolyase involvement. Biochim Biophys Acta 632, 121-130.

Stipanuk, M. H., Hirschberger, L. L. \& de la Rosa, J. (1987). Cysteinesulfinic acid, hypotaurine, and taurine: reversed-phase high-performance liquid chromatography. Methods Enzymol $143,155-160$.

Thauer, R. K., Jungermann, K. \& Decker, K. (1977). Energy conservation in chemotrophic anaerobic bacteria. Bacteriol Rev $41,100-180$.

Tschech, A. \& Pfennig, N. (1984). Growth yield increase linked to caffeate reduction in Acetobacterium woodii. Arch Microbiol 137, 163-167.

Voet, D. \& Voet, J. G. (1992). Biochemie, 1st edn. Weinheim: Verlag Chemie.

Wanner, U., Kemmler, J., Weilenmann, H. U., Egli, T. \& Auling, G. (1990). Isolation and growth of a bacterium able to degrade nitrilotriacetic acid under denitrifying conditions. Biodegradation $1,31-42$.

Widdel, F. \& Pfennig, N. (1981). Studies on dissimilatory sulfatereducing bacteria that decompose fatty acids. I. Isolation of new sulfate-reducing bacteria enriched with acetate from saline environments. Description of Desulfobacter postgatei gen. nov., sp. nov. Arch Microbiol 129, 395-400.

Widdel, F., Kohring, G. W. \& Mayer, F. (1983). Studies on dissimilatory sulfate-reducing bacteria that decompose fatty acids. III. Characterization of the filamentous gliding Desulfonema limicola gen. nov. sp. nov., and Desulfonema magnum sp. nov. Arch Microbiol 134, 286-294.

Zehnder, A. J. B. \& Wuhrmann, K. (1976). Titanium(III) citrate as a non-toxic oxidation-reduction buffering system for the culture of obligate anaerobes. Science 194, 1165-1166.

Received 18 October 1996; revised 17 December 1996; accepted 21 January 1997. 